\title{
Goals, ways and the roots of our economic crisis
}

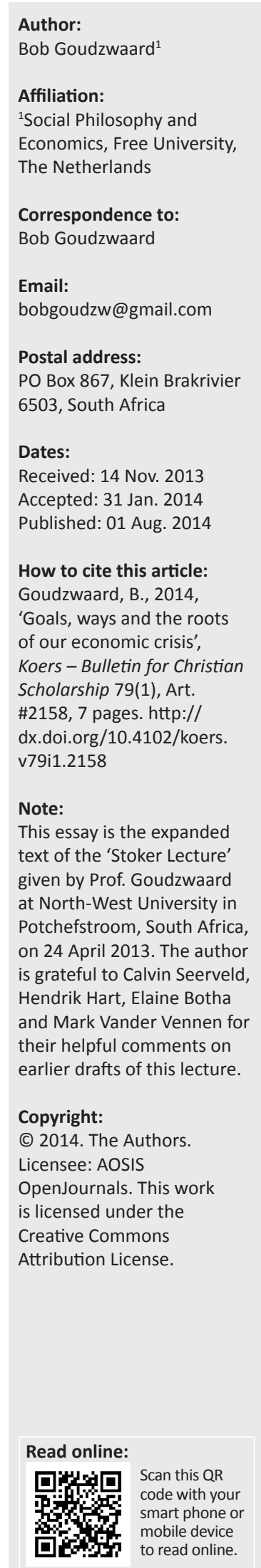

This article deals with the question if and how far religious points of view and messages of churches involved matter in the analysis of the roots of the present global economic crisis, and even more in the discussion about how to overcome the crisis itself. Economic experts such as Stiglitz point to the presence of factors such as greed, fear and utmost selfish behaviour. It inevitably leads to the ethical, but in fact also the religious question of how far people, especially economic agents, can go in the pursuit of their own economic interests without doing harm to others. Jesus asked his disciples to follow him: with Bonhoeffer, we could call that a Way-orientation. Where and how far can a conflict therefore arise between human goalorientations, on the one hand, and a biblical Way-orientation, on the other hand? And is it indeed relevant when considering our present economic crisis? This article defends the last position, describing some categories (such as the choice of ultimate meaning, the sacro-sanctity of chosen instruments, and the demonisation of opponents) which indicate that the borderline has been passed between responsible and irresponsible goal-orientations. The glorification of greed and the delegation of ultimate power to financial markets indicate that at this moment elements of idolatry (or the obedience to Mammon) are at hand. They are also aggravating the present economic crisis. This implies that returning to the choice for decisive normative Way-orientations in economic life is possibly the only true way out of the present economic crisis.

Doelwitte, weë en die wortels van ons ekonomiese krisis. Hierdie artikel vra of, en tot watter mate, religieuse standpunte, insluitend die standpunte van die kerke wat betrokke is, saak maak in die analise van die wortels van die huidige globale ekonomiese krisis, en selfs meer in die bespreking van hoe om die krisis self te oorkom. Ekonomiese kundiges, soos Stiglitz, wys op die teenwoordigheid van faktore soos hebsug, vrees en uiterste selfsugtige gedrag. Dit lei onvermydelik tot die etiese (en eintlik ook religieuse) vraag van hoe ver persone, veral ekonomiese agente, kan gaan in die najaag van hulle eie ekonomiese belange sonder om ander skade te berokken. Jesus het sy dissipels gevra om hom te volg: saam met Bonhoeffer kan ons dit 'n Weg-oriëntasie noem. Waar en hoe ver kan 'n konflik tussen menslike doel-oriëntasies aan die een kant, en 'n Bybelse weg-oriëntasie aan die ander kant ontstaan? En is dit inderdaad relevant wanneer ons ons huidige ekonomiese krisis bekyk? Hierdie artikel verdedig laasgenoemde posisie en beskryf van die kategorieë (soos die keuse van finale betekenis, die onaantasbaarheid van gekose instrumente en die demonisering van opponente) wat aantoon dat die grenslyn tussen verantwoordelike en onverantwoordelike doel-oriëntasies oorgesteek word. Die verheerliking van hebsug en die delegeer van finale mag na finansiële markte dui daarop dat elemente van idolatrie (of gehoorsaamheid aan Mammon) inderdaad tans teenwoordig is en die huidige ekonomiese krisis vererger. Dit impliseer dat die terugkeer na 'n keuse vir bepalende normatiewe Weg-oriëntasies in die ekonomiese lewe moontlik die enigste ware Weg uit vir die huidige ekonomiese krisis is.

\section{Introduction}

Every year the United Nations publishes 'outlooks' on the world economic situation. This is not usually very hopeful material. But the most recent report by the Department of Economic and Social Affairs, United Nations (2013), entitled 'World Economic Situation and Prospects 2013', is truly pessimistic. ${ }^{1}$ It states: 'The world economy is on the brink of another major downturn' (Department of Economic and Social Affairs 2013:3). It adds: 'During 2012, global economic growth has weakened further,' bringing with it a heightened 'risk of a double-dip global recession' (ibid:1, 27). ${ }^{2}$

1.The report is a joint product of the United Nations Department of Economic and Social Affairs (UN/DESA), the United Nations Conference on Trade and Development (UNCTAD) and the five United Nations regional commissions (Economic Commission for Africa (ECA), Economic Commission for Europe (ECE), Economic Commission for Latin America and the Caribbean (ECLAC), Economic and Social Commission for Asia and the Pacific (ESCAP) and Economic and Social Commission for Western Asia (ESCWA).

2.The report notes that: 'A growing number of developed economies have fallen into a double-dip recession'. 
One of the main causes of this adverse development, the report says, is that many governments are busy fighting their budget deficits, which are much too high. They need to cut their expenses, which then leads to more unemployment. This is a sad story, also for the faltering South African economy. And it begs the question: What are the factors or causes that have led to this current sad situation?

It is not my purpose in this article to provide a detailed discussion of global economic problems. I have another purpose in mind. The discussions about today's crisis, in the reports from the World Council of Churches (2009), almost completely neglect faith-oriented perspectives, including the testimonies and witnesses of Christian churches. ${ }^{3}$ I would like to explain why, in my view, this omission is harmful, and even substantially diminishes the prospects of our present economic crisis taking a turn for the better.

Usually people say that economic crises are value-neutral or of an a-religious nature. Economic crises are thus best handled by economic experts, without intervention by political know-alls or moralistic preachers. At first this sounds quite reasonable. But then what prevented all of this economic expertise from redirecting today's economy away from the brink of another possible major downturn? Is it possible, then, that we are not really on value-free, neutral ground?

A great deal has already been published about the causes of today's crisis. The most competent analysts, such as Nobel prize-winner Joseph Stiglitz (2010), have concluded that it started with an overflow of newly created money entering the Western economies, mainly in the form of speculative credits created by a large number of greedy banks. Already here it is clear that we are no longer on value-free ground. Stiglitz has touched on a cultural dimension - the dimension of greed. Cheap money, he explains, also awakened the lust of many governments to spend far more than their taxpayers were willing to give to them. Since 2002 money has been so easily available that a number of states fell into the trap of delivering huge programmes without adding to the fiscal burden of their citizens. Think, for example, of the Greek government, which now finds itself purely at the mercy of the financial markets. And in cases like this the financial markets have just one purpose: to get their money back. Yet they live in fear that they will never see their money again.

\section{Two basic orientations}

The entire world economy thus seems to be caught in the grip of both greed and fear. Moreover, it seems to have fallen prey to a multitude of selfish agents who are driven by powerful financial goals. Now one could, of course, argue that greed, the fear of losing money, and the presence of harsh financial goals are in no way new phenomena. And because they

3.See, for example, a number of reports from the World Council of Churches, includin 'Statement on just finance and the economy of life' (World Council of Churches n.d. [a]); the 'São Paulo statement on international financial transformation for the economy of life' (World Council of Churches n.d. [b]); and the background paper by Barry Herman entitled 'Financial services, economic needs and global financial by Barry Herman entitled 'Financial services, econ
architecture' (World Council of Churches n.d. [c]). are not new, one could also argue, there is not any basis for using these to explain the roots of today's economic crisis. I certainly agree that greed belongs to all ages. But I would like to suggest that this does not imply that there is no connection between greed and today's crisis. For example, is today's vigorous pursuit of financial goals not enabled as never before - by the unprecedented freedom given to contemporary financial markets? This also raises a related ethical question: How far, in the context of today's largely privatised monetary system, can people pursue financial goals such as these before they begin to threaten their own future and the future of others?

But this is much more than merely an ethical question. Addressing a Christian audience today, I would like to draw your attention to the unavoidable fact that risking your own future and the future of others also has a religious dimension. When Jesus asked his disciples to follow him, he was asking them to orient their lives around His way of love, truth, justice and compassion. That is a different kind of orientation from orienting your or my life towards personal goals of material acquisition. There is a difference between what we could call a Way-orientation, the orientation inspired by values and norms such as love, justice, truth and compassion, and a Goal-orientation, which orients our actions to what we ourselves want to reach or to preserve. ${ }^{4}$

Of course, these two orientations can collide. Suppose they do collide. If we pursue goals that involve enhancing our own economic position, how can we prevent doing harm to others?

As we shall see, this is a key question if we wish both to understand the root causes of today's economic crisis and to search for potential ways out. Let us therefore explore this question in more depth.

Let me take as our starting point that all of us have goals and plans in our lives, and we are often busy trying to accomplish them. In fact, without short- and long-term goals, life is almost impossible. Families need prospects, and no corporation can exist without some kind of business plan. And you and I would never vote for a political party without some kind of programme. But it is also true that our lives and societies would become chaotic without fundamental orientations towards ways of life or norms for life. In the Christian worldview love, truth, justice, compassion and stewardship are destined for all people to be ways or paths to walk on. Even peace is called 'a way' in the New Testament, a way that is clearly different from the goal of guaranteed safety. In Luke 1:79, Zachariah, for example, the father of John the Baptist, prophesied that the coming Saviour 'will guide our feet into the path of peace'.

But does that necessarily imply that by definition there exists a deep tension between these two orientations, between

4.All of the world's major religions have as a trademark being oriented to a way. The oldest name applied to Christians, according to the book of Acts, which was those who 'belonged to the Way' (Ac 9:2). Jesus said of himself, 'I am the way and the truth and the life' (Jn 14:6). Islam means literally 'obedience, submission' to the truth and the life' (Jn 14:6). Islam means literally 'obedience, submission' to the
commandments. Buddhism teaches the sevenfold path; Taoism refers in its name (Tao means 'way') to going on a way. 
goals and ways? My answer is no. These orientations can go hand in hand. Our own personal goals can certainly be expressions of life-affirming ways of love, justice, compassion and stewardship. But that is only possible if we allow the orientation towards ways of life to take the lead in every critical situation. Self-oriented goals should always remain subservient to what following the Way requires of us. Our own goals need to yield, to give in, or even be given up at the moment that they would lead us astray. To give a brief example: striving for a nation's security or seeking to preserve a people's identity can be legitimate goals. But great tensions arise if people pursue them at any cost, if people are not willing to accept any ethical restraint in the practical realisation of these goals (Klapwijk 1987). ${ }^{5}$

At first glance this dilemma is of the same character as the two types of ethic that the German philosopher Max Weber formulated about a century ago. He made the famous distinction between 'Gesinnungsethik' and 'Verantwortungsethik', between the 'ethics of conviction' and the 'ethics of responsibility' (Weber 2009; see also: Enderle 2007). For Weber (2009), responsibility must take the lead. But it is remarkable that Dietrich Bonhoeffer (1955), in his well-known treatise on Ethics (written between 1940 and 1943), refused to make this distinction his own (Blackburn, Bonhoeffer \& Weil 2004). Unlike Max Weber, for Bonhoeffer the word 'responsibility' was characterised by the willingness to obey Jesus' demand to follow Him even if this has severe personal consequences. Bonhoeffer's ethics was thus not centred on the question of doing more or less good, but on how Jesus Christ as Lord is given shape in our lives and in the life of our societies. 'Gleichgestaltung', living and acting in conformity with our Lord Jesus, was the heart of his ethics (Bonhoeffer 1955).

Bonhoeffer's (1955) ethics is also called the 'Ethics of the Way'. His favourite psalm was Psalm 119. Brian Brock (2005:11), in his interpretation of Bonhoeffer's comments on Psalm 119, wrote: 'The Psalter frames the concept of instruction or command with a dynamic understanding of human behaviour. Commands mark out a path, stand alongside something continuous and ongoing'. This is similar to Martin Buber's (1997) translation of the Psalms. Buber always translated the word 'Torah' as 'Weisung', meaning 'guidance', guidance coming to us from God's fatherly hand. This is much different than a set of rigid statutes. Buber's reading suggests that Psalm 119:96, 'I have seen an end to everything, but your Way is very wide', can be read as 'I have seen an end to everything, but your Way is one that widens as we follow it, step by step'.

I will try to take the same approach. This means that my vantage point starts from the assumption that referring to a Way-orientation, both in our own lives and in the life of our societies, implies much more than accepting some kind of restraint or boundary in the pursuit of our own goals. A

5.In a play on words possible in Dutch but not in English, S.U. Zuidema described a pattern by which people who pursue societal goals at any cost have exchanged 'beginselen' - meaning 'principles', with a connotation of 'first principles' or creational norms - for 'eindselen' - meaning their own absolute 'ends' or goals. true Way-orientation does not restrict life but encompasses life. Ways of life are like water surrounding a fish. They form the climate in which we can breathe freely and are enabled to choose truly responsible goals. But if we reject that perspective, and especially if our own self-oriented goals take the lead, then sooner or later ways such as justice, love and stewardship become distorted or crooked. Then they also lead to deep, unavoidable crises in our personal and social lives.

Let me illustrate all this by exploring some basic criteria that could help us to find a line of demarcation: a distinct line between the legitimate pursuit of one's own goals and targets, on the one hand, and the abyss of neglecting any kind of Way-orientation, on the other. Though this may seem like a highly theoretical endeavour, it is not. We need criteria like these to dig more deeply into the roots and sources of today's economic crisis.

\section{Four basic criteria}

The first criterion is related to the central significance of the concept of meaning in all that people think and do. 'Meaning' was the first word of the opening sentence of Herman Dooyeweerd's (1997) A new critique of theoretical thought. There he wrote: 'Meaning is the mode (or way) of being of all that exists' (my translation). We may call this primary meaning. Primary meaning is meaning which comes to us from beyond ourselves. It may come from the Torah, or from Jesus' teachings, or from the future (I think here of Bonhoeffer's concept of living in 'das Vorletzte', the 'things before the last'). It may also come to us as engraved in God's creation. Alongside of that there are kinds of meaning that originate in our own ways of living and thinking, meaning that we as human beings ascribe meaning to things. We may call this secondary meaning (Smit 1987). ${ }^{6}$ An inescapable aspect of being human is that we actively seek to make sense of the events of our lives and of our world (Smit 1987). ${ }^{7}$

Primary meaning is, however, not a human construct. It is always perceived as a given meaning. It comes to us or is revealed to us as ways to walk on or paths to walk down. Martin Buber (1997) once wrote that feelings of sympathy dwell within us as human beings, but human beings themselves dwell within love. That is primary, given meaning. At the same time, however, our own self-oriented goals can become so important that we begin to ascribe to them the status of primary meaning. We can become so strongly attached to what we want to achieve or preserve at all costs that we fall into the temptation of considering these goals a matter of ultimate meaning in our lives. For example, our quest for guaranteed security and survival can become so important that we consider it worthy enough to sacrifice everything to achieve it.

6.Philosopher of history M.C. Smit developed the theme of primary and secondary meaning in the context of what he calls 'first history' and 'second history'. He writes, meaning in the context of what he calls 'first history' and 'second history'. He writes, 'in every moment of history, be it of the world or of the individual person, there is an irresistable [sic] coming of integral meaning' (Smit 1987:264). For more on his development of this theme, see his 'Reflections on history and the time of history" d.:253-274)

7.Smit (1987:263) writes, '... since man can never step out of meaning, a struggle is going on within the very meaning itself of history, of love, of peace, etc'. 
But then indeed a deep tension becomes apparent. For there can be only one source of ultimate meaning. If achieving your or my own goals becomes our ultimate purpose in life, then we make these goals absolute, which implies that we reject any critique of them from the perspective of Ways that are given to us. Then we no longer have room for following someone who once was willing to give up his entire life in love for and obedience to his heavenly father.

A second criterion comes to the fore when we look closely at what happens to people's values as they strive for absolute goals. Their attitudes towards good and bad change radically. They bend and twist norms like truth, love and justice in such a way that these norms or values legitimate in advance what they have in mind. Then you can indeed give yourself permission to neglect the real interests of others in economic and financial affairs.

Incidentally, this is and always has been the birthmark of all great ideologies. Often ideologies are seen solely as broad social phenomena, but the process of distorting norms and values can also take place in our personal lives, in our own hearts and minds. Bonhoeffer (2005) wrote about 'Doppelgänger', a counterpart or 'double' of oneself that comes to life as soon as we read the Scriptures from a preselected, unassailable position - the heavenly double of my earthly ego'. Then the Bible merely echoes what we want to hear and believe.

After we ascribe ultimate meaning to our own goals, and after we distort fundamental values from the perspective of our goals, there is a third criterion for understanding when and where people cross the line between striving for acceptable goals, on the one hand, and pursuing absolute goals, on the other hand, thus rejecting any kind of primary meaning. When human goals become absolute, something changes in the realm of the methods and instruments people use to achieve their goals. Certain means or methods, such as violence, can become indispensable to reaching our goals. This implies that sooner or later we need to give these means free rein if they are to achieve our prized objective. But at that point they take the lead in our lives and gain power over us. We become controlled by what we first saw as our liberator. Then, in a dynamic, rapidly changing modern universe the means will take the lead - and ultimately betray us, whilst usually also doing great harm to others. This is the story of many people in history who choose violence, and who then can no longer live without violence. And then, instead of saints, it is idols who are marching in.

This reversal of control, by which people hand over their control to the means they believe in, can also happen at the level of the institutions or structures of society. A society can become so thoroughly power-driven or money-oriented that its main institutions become entrenched as indispensable forces, at least for the privileged, for becoming richer and richer in an unlimited way. Then the privileged become unavoidably subservient to their new gods.
A fourth criterion is the remarkable change that takes place in people's choice of friends and enemies. Those who may prevent us from reaching our goals become our enemies. This can go so far that we seek their elimination. This pattern is what Réné Girard has written about: the mechanism by which we create scapegoats in human societies (see for example: Girard 1977, 1978a, 1978b, 1989, 2007). During the Cold War, for example, communists were seen as the concentration of all evil, whilst in their turn they saw capitalists as the ultimate source of evil. In our time and place - South Africa - it sometimes appears that a number of people turn the current (mainly black) majority government into a scapegoat for everything that goes wrong.

I have sketched four criteria for determining when the pursuit of personal, self-chosen goals strays from true, given ways of life. Let me try now to summarise them in a preliminary conclusion. Ethically speaking, there is nothing wrong with pursuing concrete goals, either in our personal lives or in the life of a society. Our goals can serve or be expressions of given ways of life. But we should always be aware that such a pursuit can easily lead us astray. We are led astray if one or more goals become the decisive point of orientation in our lives and assumes the place of ultimate meaning. At that point, everyone and everything must clear a path for our goals to be achieved. Such goals will seduce us to bend or reinterpret our own norms and values in such a way that they justify a priori the means or tools we use to achieve our ends. They are sanctified, so to speak: the end justifies the means. And eventually, having handed over to them our control, they enslave us whilst also causing substantial harm to the interests of the poor and the weak.

My own conviction has grown in the past few decades that crossing or not crossing this line of demarcation is the deepest controversy in political and economic life. The deepest controversy for political and social leaders and business people is not between liberals and conservatives, between planners or free marketers. It is rather between those who are willing to adhere to ways of justice and compassion and those who persist in pursuing their own self-interested goals under all circumstances. In fact, there are only two options available. Either we relativise our own goals in view of obeying the principles of the Way, or we relativise the principles of the Way in view of our absolute, self-oriented goals, goals that we wish to achieve or preserve at all cost. There is no possible compromise between these two attitudes. It is a choice lying on the sharp edge of a sword. It is similar to what Jesus once said in Matthew 6:24: 'You cannot serve two masters. You cannot serve God and Mammon'. The real choice lies in what or whom we ultimately serve.

\section{Returning to the crisis - Two indications of goal possession}

Now let us return to our original question, which had to do with the root causes of today's global economic and financial crisis. At this point Christians need to be completely honest. Adherence to extreme forms of greed, self-centredness, 
or blind nationalism unfortunately is also found amongst Christians. Let us not simply judge others.

But that does not diminish the significance of the ultimate choice confronting all of us, Christians as well as nonChristians, persons as well as nations, also in relation to economic affairs. Is today's economic crisis merely a question of faulty economic insights, flawed economic structures, failing policies and an unfortunate confluence of circumstances? Or is there much more going on? I opt unreservedly for the second choice.

At the beginning of this article we briefly encountered aspects of greed, of powerful selfish desires, of harsh demands originating in fear, and of non-negotiable goals. This is a beginning indication of the possible root causes of today's crisis. In and of themselves, however, they may not yet indicate the presence of absolutised goals or idolatry. But in view of some of the criteria I mentioned earlier, let me describe two strong indications that absolutised goals and modern idolatry are indeed fully present today.

The first indication starts with a quotation that has now become famous: 'Greed is good, greed is right. You can be greedy and still feel good about yourself'. These words, spoken by Michael Douglas as Gordon Gekko in the 1987 movie Wall Street, quickly became widely applauded (see Stone 1987). The Economist, commenting on the slogan 'Greed is good', even wrote that these words seemed to capture the spirit of the decade (see Bishop 2002). In the February 2010 edition of CBS's Money watch, Robert Pagliarini (2010) put it even more strongly:

Greed is good. Embrace it, love it. In fact greed may be the one thing that can save us: ... [So] stop putting yourself last, and stop sacrificing your goals and dreams. Tap into your inner Gordon Gekko and relentlessly pursue your happiness. (n.p.)

Here we recognise what happens in the process of attaching ultimate meaning to self-oriented goals: you bend and change your norms and values. They need to make the way entirely clear for the unrestricted pursuit of your own ends. The UNCTAD 2009 report entitled 'The global economic crisis: Systemic failures and multilateral remedies', makes a similar remark where it says:

No doubt without the greed of too many agents trying to squeeze double-digit returns out of an economic system that grows only in the lower single-digit range, the crisis would not have erupted with such force. (n.p.)

Yet, stated Pagliarini (2010), greed is perhaps the one thing that can save us. Is not 'saving' a religious word? Surely, then, another saviour has come forward. Or, as Martin Landauer (2010) recently said: 'God is a luxury I can't afford'.

A second indication, this time of growing idolatry, is the changing role of financial markets in today's global economy. Of course, money and finance are not bad in themselves. But they need to remain within their original role of serving people, serving the world economy. Along the way, however, their role has changed dramatically. The so-called real economy now serves the financial markets. Many governments today have a widespread fear of what the financial markets might do to their economies. Financial markets can praise or break an economy simply according to their own speculative whims. George Soros (1998), the wellknown expert on financial markets, recently stated that the financial markets have now assumed the driver's seat, from which they steer and control entire economies. Or, as Susan George and her colleagues wrote: 'The world is ... undergoing a crisis ... of the system in which the real economy has become subservient to the financial economy' (George et al. 2008).

Something important is happening here. Here we discern a trend that can be observed whenever in human history goals become absolute: the means needed to achieve the goals are given a place of privilege. And from that position they then take the lead.

In this case idolatrous powers are not bestowed upon the party machinery or military violence. Now they are bestowed upon the monetary system. In a greed-oriented society, sooner or later the means - in this case the monetary system - take control and exercise power with a decisive, even tyrannical voice. At the opening of the first Christian-Social Congress in 1891, Abraham Kuyper spoke the famous words: 'Our modern society has bent its knees deeply before Mammon'8 (see Skillen 2011). What began as a tool for creating more wealth has now turned into a tyrannical power, an idol from whose harsh rules one can scarcely escape.

\section{A possible way out}

If the present economic crisis is indeed rooted so deeply in forms of Mammonism - the term comes from Russian philosopher Nicolai Berdyaev (1901), ${ }^{9}$ so that our society is ensnared by absolutised goals spreading fear and even terror around them, what, then, can be done?

Exiled from Russia because of his Christian convictions, Berdyaev, reflecting back on the Russian Revolution of 1917, wrote that sometimes in human history the surface level of reality is scraped away, so that we see deeper levels of human desires and often evil motivations. He called this 'a small apocalypse'.10 Something like this scraping away process seems to be occurring today. On the one hand, we see an open manifestation of greed and corruption, with unbelievably huge consequences. On the other hand, we observe the ineptness of the standard remedies for finding a way out of today's crisis. Decision-makers typically advocate and long for a rapid return of strong economic growth, for example. But that solution entirely contradicts the scientifically based conclusion that the earth and its extremely vulnerable ecosystems simply cannot endure a full restoration of robust 8.Kuyper's address, entitled The social problem and the Christian religion, has been published in English as The problem of poverty.

9.Berdyaev (1901:37) wrote: 'The economism of our time stands for the loss of a spiritual centre. It is the Mammonism which has become the decisive power of our time, which honours nothing more than the golden calf'.

10.For a further analysis, see Ignatov (1997). 
material economic growth, especially not in the world's richest countries. If we do not want to risk life on this planet as a whole, then this proposed way out of the crisis is simply not available as a viable option. So now we need to earnestly ask ourselves: Has the time not arrived to come to our senses? Now that so many of our own plans have failed, has not a Way-oriented turning of our economies to true social justice and stewardship become the only realistic possibility, not just for people of faith, but even more for a deeply secular world?

Faced with this dilemma, a lesson from the past may be helpful. Here I think of the years 1939 and 1940, when Great Britain was confronted with the demon of rising Nazi terror. The courage of a Winston Churchill was needed to convert the British economy, in the shortest time possible, from a peace-oriented economy to a full-fledged war economy. That required a large increase of investments in the defence industry which could be financed only by means of a corresponding substantial slowdown in the growth of material consumption by the British people. British society had to set free, as it were, or release the resources needed to achieve that new objective by consciously lowering its own level of consumption - at the time Lord Keynes spoke of the need for what he called 'forced savings' (Keynes 1940).

Do we not need something similar in our time? Today, too, a sincere fight must be fought at several levels:

- a fight against greed as soon as it damages the interests of the weak

- a fight against the towering dominion of global financial markets

- a fight to give more people work and jobs

- a fight to better protect our environment

- a fight against an absurd waste of energy and other resources.

At the same time it is now becoming increasingly evident for a growing number of people that these goals are far more urgent and significant than striving for ever-higher levels of consumption, especially in countries that are already rich. If you and I and others say wholeheartedly 'yes' to this statement, then in principle a solution is possible. It is the solution of an economic trade-off which is quite similar to what took place more than seventy years ago during England's deeply threatened social and political existence.

Let me try to explain. When principles of social justice are allowed to rule, they first call for a strong correction of a global monetary system which has become far too unrestricted, a jungle-oriented system which has become a casino-temple of economic greed. Viewed from any kind of Way-orientation, it is simply unacceptable that hugely speculative capital flows ricochet around the world, busily speculating even against national currencies. Driven by considerations of self-enrichment, they force a depreciation in the value of those currencies. Strong measures are therefore needed to restructure our monetary system. Private commercial banks should no longer be entitled to freely create huge sums of money. Money should again be recognised and treated as a public asset instead of as the privatised hobby of the wealthy.

But there is more. There is also the norm of good stewardship. It calls us to wage a genuine fight against levels of unemployment that are far too high, and against putting further extreme pressure on the world's eco-system, which is already far too overburdened. These two endeavours call for a substantial growth, not in the capital-intensive industrial sectors, but rather in the labour-intensive segments of our economies, where social, natural and human capital urgently needs to be protected and strengthened (think of the investments needed for cleaner energy, improved safety nets, environmental protection, basic housing, and good education for all). In this way a substantial boost can be given to the level of employment in each society, through publicly funded, cooperative and private-enterprise initiatives. But just as in the case of Great Britain during war time, the economic basis for financing this should be sought largely through restraint in the growth of material consumption, especially luxury consumption. It should surely not be sought in overexpanding the supply of money and credit. Let us remind ourselves that because these types of employment are highly labour-intensive, more new jobs can be created through these new investments than by, for example, increasing the production and consumption of more airplanes or automobiles. Indeed, within the framework of this economic trade-off, a significant rise in employment levels, combined with a better care for the environment, can occur even within the same national product.

This is not the time or place to offer a detailed and elaborate answer to the question of how to organise all this. But perhaps three hints will help.

Firstly, this major shift can become implemented - and this is indeed the best way - through voluntary restraints on the growth of personal income and consumption. What a blessing it would be if, instead of continuing down the path of greed, employers and employees could agree to establish new employment funds across the entire economy, financed, on the one hand, by employers waiving bonuses and higher incomes for themselves and, on the other hand, by labour unions which are willing to earmark or reserve for that goal a substantial part of their initial demand for higher wages. This path may seem a bridge too far in developing economies or in polarised societies such as South Africa. Yet it is important to note that it is not beyond the realm of what is currently done in some Western economies. In the 1990s, for example, the Dutch Christian Labour Union (the second largest labour union in the Netherlands) proposed to freeze real wage demands for a maximum of four years in exchange for increased employment, more care for the environment, and improvements in the quality of work. The proposal met with $67 \%$ approval by members, was accepted by management and has been credited with helping to shield the Dutch economy from the worst effects of external economic shocks. Similarly, around the same time the largest industrial union in western Germany, I-G Metall, offered to freeze real wages 
for five years in exchange for more jobs, especially in eastern Germany. ${ }^{11}$

A second possibility is to increase substantially the taxation of luxury consumption or the taxes on non-basic goods. In that case, the revenue brought in should be earmarked from the beginning to the growth of labour-intensive investments in social, natural and human capital.

A third possibility is to implement a global tax on capital movements (the so-called Tobin-tax). A levy of no more than a few thousandths of one percentage point could provide a substantial source for financing the international struggle against unemployment. And it would serve as a major antispeculation measure.

Are not these the types of concrete step that we most need today? Many black, often uneducated workers in South Africa are desperately looking for any kind of employment. But I also think of an article from BBC news (2013) about Spain, where $55 \%$ of young people are now unemployed, simply because the financial markets are demanding more and more cuts to government expenditure. Such a high rate of unemployment of young people is not just a shame: it is close to a crime, an absurd waste of human potential and a flagrant rejection of God's ordinance of good stewardship. Here - and not elsewhere - is where the process of economic healing needs to begin.

A continuing crisis is not necessary. A number of measures can substantially reduce the level of unemployment. But these measures cannot stand on their own. In fact, at the deepest level, only one thing is needed: that we set aside greed and prefer the justice of God above the injustice of Mammon in our political and economic behaviour.

\section{Acknowledgements \\ Competing interests}

The author declares that he has no financial or personal relationship(s) that may have inappropriately influenced him in writing this article.

\section{References}

BBC news, 2013, 'Spain unemployment rate hit a record: Youth rate at 55\%', viewed 24 January, from http://www.bbc.co.uk/news/business-21180371

Berdyaev, N., 1901, Das neue mittelalter: Betrachtungen über das schicksal Russlands und Europas, Otto Reichl Verlag, Tübingen.

Bishop, M., 2002, 'Is greed good?', The Economist, viewed 14 October 2013, from http://www.cfo.com/article.cfm/3004792/1/c_2984333

Blackburn, V., Bonhoeffer, D. \& Weil, S., 2004, A study in Christian responsiveness (Religions and discourse), Peter Lang Publishers Inc., New York.

11.For an expanded articulation of this proposal, see Bob Goudzwaard and Harry de Lange (1995:131-135). There the authors write: 'We do not mean that certain specific groups - people who cannot meet their specific needs, including recipients of inadequate government benefits - ought not to receive wage and salary increases. But ... we reject the suggestion that general, across-the-board hikes must be achieved in order to restore the economy' (ibid:132)
Bonhoeffer, D., 1955, Ethics, Simon \& Schuster, New York.

Bonhoeffer, D., 2005, Creation and fall: Dietrich Bonhoeffer works, vol. 3, Fortress Press, Minneapolis.

Brock, B., 2005, 'Bonhoeffer and the Bible in Christian ethics: Psalm 119, the mandates, and ethics as a way', Studies in Christian Ethics 18(3), 7-29. http:// dx.doi.org/10.1177/0953946805058794

Buber, M., 1997, Ich und du, Gütersloher Verlagshaus, München.

Department of Economic and Social Affairs, United Nations, 2013, World economic situation and prospects 2013, viewed n.d., from http://www.un.org/en/ development/desa/policy/wesp/wesp_current/wesp2013.pdf

Dooyeweerd, H., 1997, A new critique of theoretical thought, Edwin Mellen Press, Lewiston, New York.

Enderle, G., 2007, 'The ethics of conviction versus the ethics of responsibility', Journal of Human Values 13(2), 83-94. http://dx.doi.org/10.1177/097168580701300202

George, S., Gills, B.K., Van der Stichele, M. \& Wachtel, H.M., 2008, 'The transnational institute working group on the global financial and economic crisis: Statement on the G20 summit on the financial crisis', in Alternative regionalisms, viewed n.d. from http://www.tni.org/archives/tnifinancialcrisisg20statement

Girard, R., 1977, Violence and the sacred, transl. P. Gregory, Johns Hopkins University Press, Baltimore.

Girard, R., 1978a, I saw Satan fall like lightning, transl. and foreword by J.G. Williams, Orbis Books, Maryknoll.

Girard, R., 1978b, Things hidden since the foundation of the world, transl. S. Bann \& M. Metteer, Stanford University Press, Stanford.

Girard, R., 1989, The scapegoat, transl. Y. Freccero, Johns Hopkins University Press, Baltimore.

Girard, R., 2007, Evolution and conversion: Dialogues on the origin of culture, Continuum International Publishing, New York.

Goudzwaard, B. \& De Lange, H., 1995, Beyond poverty and affluence: Toward an economy of care, Wm. B. Eerdmans Publishing, Grand Rapids, Michigan.

Ignatov, A., 1997, Russian philosophy of history: The ideas and current influence of Solovyov and Berdyaev, Köln BundesInstitut für Ostwissenschaftliche Studien nr M3

Keynes, J.M., 1940, How to pray for the war: A radical plan for the Chancellor of the Exchequer, McMillan Press, London.

Klapwijk, J., 1987, 'Reformational philosophy on the boundary between the past and the future', Philosophia Reformata 52, 17-18.

Landauer, M., 2010, 'Business and money section', Time, 23 September, n.p.

Pagliarini, R., 2010, 'Greed is good: Why you need to tap into your inner Gordon Gekko', Money watch, viewed 14 October 2013, from http://www.cbsnews. com/8301-505125 162-37441183/greed-is-good-why-you-need-to-tap-intoyour-inner-gordon-gekko

Skillen, J., 2011, The problem of poverty, Dordt Press, Sioux Centre, lowa.

Smit, M.C., 1987, Writings on god and history, H. Van Dyke, (ed.), Wedge Publishing Foundation, Jordon Station, Ontario.

Smit, M.C. n.d., 'Reflections on history and the time of history', in reformationalpublishingproject.com, viewed n.d., from http://www.
reformationalpublishingproject.com/pdf_books/Scanned_Books_PDF/ reformationalpublishingproject.com

Soros, G., 1998, 'The crisis of global capitalism: Open society endangered', Public Affairs, New York.

Stiglitz, J., 2010, Free fall: America, free markets, and the sinking of the world economy, W.W. Norton, New York.

Stone, O. (dir.), 1987, Wall Street, Video recording, 20th Century Fox, United States of America.

United Nations Conference on Trade and Development (UNCTAD), 2009, The globa economic crisis: Systemic failures and multilateral remedies, viewed 14 October 2013, from http://www.unctad.org/en/Docs/gds20091_en.pdf

Weber, M., 2009, Politik als beruf, Grin, München.

World Council of Churches n.d.[a], Statement on just finance and the economy of life, viewed n.d., from http://www.oikoumene.org/en/resources/documents/central-
committee/2009/report-on-public-issues/statement-on-just-finance-and-theeconomy-of-life

World Council of Churches n.d.[b], São Paulo statement: International financial transformation for the economy of life, viewed n.d., from http://www. oikoumene org/en/resources/documents/wcc-programmes/public-witness-addressingorg/en/resources/documents/wcc-programmes/public-witness-addressing power-affirming-peace/poverty-wealth-and-ecology/finance-speculation-debt/
sao-paulo-statement-international-financial-transformation-for-the-economy-oflife

World Council of Churches n.d.[c], Background paper on a new international financial architecture, viewed n.d., from http://www.oikoumene.org/en/resources/ documents/wcc-programmes/public-witness-addressing-power-affirming-peace/ poverty-wealth-and-ecology/finance-speculation-debt/background-paper-on-anew-international-financial-architecture 